UDK 528.371:551.461.2

\title{
KURŠIŲ MARIŲ IR PIETRYTINĖS BALTIJOS JŪROS DALIES VANDENS LYGIO DAUGIAMEČIU SVYRAVIMŲ ANALIZĖS METODOLOGINIAI YPATUMAI
}

\author{
Inga Dailidienè, Algirdas Stankevičius \\ Jūriniu tyrimu centras, Taikos pr. 26, LT-91149 Klaipéda, Lietuva, el. paštas: inga.dailideniene@ delfi.lt \\ Benediktas Tilickis \\ Klaipédos universitetas, H. Manto g. 84, LT-92294 Klaipéda, Lietuva, el. paštas: benediktas.tilickis@ku.lt
}

Iteikta 200311 26, priimta 20040210

\begin{abstract}
Santrauka. Šiuolaikiniai klimato kaitos tyrimai bei klimato šiltejjimo problemų sprendimas susiję su geofizinių reiškiniu bei hidrologinių elementų režimo kaitos analize. Susirūpinimą kelia pastaraisiais 20 a. dešimtmečiais spartesnis vandens lygio kilimas bei su tuo tiesiogiai susiję krantų ardymo, sausumos užliejimo, ekologinès pusiausvyros pažeidimo problemos. Ne mažiau svarbus veiksnys, lemiantis daugiametį vandens lygio kitimą Baltijos jūroje, yra Žemès plutos judejimas. Straipsnyje, remiantis Aplinkos ministerijos Jürinių tyrimų centro duomenimis, analizuojamas daugiametis vandens lygio kitimas pietrytineje Baltijos jūros dalyje ir Kuršių mariose.
\end{abstract}

Raktažodžiai: vandens lygis, kitimas, dėsningumas, tendencija, Kuršių marios, Klaipèdos sąsiauris, Baltijos jūra.

\section{Ivadas}

Vandens lygis, jo paros, sezoninè kaita, daugiametis režimas nuo seniausių laikų domino ne tik su jūros verslais susijusius žmones. Informacija apie vandens lygio kaitą būtina rekonstruojant uostus, statant gyvenvietes, miestus prie vandens objektų, ji reikalinga laivų navigacijai, saugumui užtikrinti. Vandens lygio parametrai yra vieni iš pagrindinių elementų, naudojamų hidrodinaminiams, ekologiniams modeliams kurti, taikyti bei prognozèms sudaryti. Jūrų gylių žemèlapiai ir planai būtini laivavedžiams, kur gyliai nedideli, uostų prieigose. Tačiau vandens lygis nuolat kinta. Pavyzdžiui, Klaipėdos sąsiauryje jis per parą gali pakisti apie $40 \mathrm{~cm}$, esant ekstremalioms sąlygoms - iki $140 \mathrm{~cm}$ ir daugiau. Jūrose, kur nuolat vyksta potvyniai ir atoslūgiai, vandens lygio svyravimo amplitudé per parą gali siekti $7-10 \mathrm{~m}$ ir daugiau. Sudarant tikslius tam tikro regiono batimetrinius žemèlapius, būtina apskaičiuoti vidutini daugiameti vandens lygi. Jis laikomas atskaitos tašku. Pagrindinès vandens lygio charakteristikos, būtinos vykdant jūrinių hidrotechninių irenginių statybą, turi atspindèti ne tik vidutini ar esamą režimą. Vis didesnès svarbos igyja vandens lygio reikšmių kitimas laiko atžvilgiu.

Sistemingi vandens lygio Kuršių mariose stebejjimai pradèti nuo 19 a. pradžios, Lietuvos Baltijos jūros priekrantinèje dalyje - 19 a. pabaigoje. Nuo 1998 metú šiuos darbus tęsia Aplinkos ministerijai priklausantis Jūrinių tyrimų centras.

Apie vandens lygius pietrytinëje Baltijos jūros priekrantėje, Kuršių mariose bei Aistmarèse 20 a. pradžioje pasirode pirmieji išsamūs Ch. Štelmacher, O. Maišner ir kitų autorių darbai [1-3]. Šeštame ir septintame dešimtmetyje daugiamečius vandens lygio svyravimus analizavo savo darbuose mokslininkai ir tyrinètojai E. Červinskas, J. Dubra, L. Markova, I. Nečai,
K. Vaitkevičius ir kiti. Daugiausiai demesio buvo skiriama surinkti empirinius duomenis, patikrinti ju kokybę. N. N. Lazarenko publikacijose daugiamečio vandens lygio kitimo skaičiavimo metodika pagrista ilgalaikių vandens lygio duomenų sekų analize [4]. Pastaraisiais metais daugiameti vandens lygio kitimą, priklausomai nuo eustatinių ir izoastinių procesu itakos, analizavo D. Jarmalavičius, G. Žilinskas [5, 6]. Tačiau iš esmès daugiamečio vandens lygio tyrimams Lietuvoje, kaip ir kitiems hidrodinaminių, okeanologiniu procesų pažinimo klausimams, kol kas skiriama nepakankamai dèmesio, nors yra sukaupta nemažai pirminès medžiagos bei duomenų.

Dèl pastaruoju metu kylančio pasaulinio vandens lygio vis būtinesnè tampa globali vandens lygio kaitos analizè, kuri neimanoma neatliekant regioninio detalizavimo. Pavyzdžiui, vandens lygio duomenis lyginti su kitų Baltijos šalių sudėtinga dèl skirtingų aukščiu sistemų. Lietuvoje, kaip ir kitose buvusiose Rytų bloko šalyse (Estijoje, Rusijoje, Latvijoje, Lenkijoje), vandens lygis matuojamas remiantis Baltijos aukščiu sistema (BS) - vandens lygio stotyse nuliniu laikomas horizontas, kurio lygis $500 \mathrm{~cm}$ žemiau Kronštato (Rusijoje, šalia Sankt Peterburgo) matuoklès nulio. Dažnai ịvairūs autoriai, nagrinejjantys vandens lygio duomenis, painioja aukščiu sistemas, taip iškraipomi reikšmių dydžiai. Pavyzdžiui, nusakant šių laikų hidrodinamines sąlygas Klaipedos uosto teritorijoje [7], vandens lygis pateikiamas vokiečiu normaliojo nulio (NN) aukščiu sistema, nors pagal ją Lietuvoje vandens lygiai matuoti tik iki 1938 m. lapkričio. Iki 1961 m. pagal ivvairias aukščiu sistemas matuoto vandens lygio archyvinius duomenis savo darbuose i Baltijos aukščiu sistemą perskaičiavo J. Dubra [8].

Daugiameti vandens lygio kilimą labiausiai lemia eustatinis vandens lygio kilimas, t. y. laipsniškas vandens 
tūrio didejjimas, susijęs su vandens temperatūros aukštėjimu šiltejjant klimatui. Klimato daugiametei kaitai taip pat būdingi cikliniai svyravimai. Dabar šiltejjimo laikotarpis [9]. Žinoma, kad daugiausia ši šiltējimo procesą veikia astronominiai, klimatiniai veiksniai, tačiau vis aktyvesni tampa ir antropogeniniai. Ivairių autoriu duomenimis, vandens lygis pasauliniame vandenyne kyla nuo $1 \mathrm{~mm}$ iki $1,9 \mathrm{~mm}$ per metus greičiu [5, 8-13]. Teoriškai šis procesas turètu būti vienodas visose jūrose. Tačiau realiai gaunami skirtingi rezultatai dèl skirtingu fizinių geografinių sąlygų. Pavyzdžiui, Baltijos jūroje pasaulinio vandenyno vandens lygio pakilimas gali pasireikšti mažiau, nes ji yra gana uždara žemyninè jūra, slūgsanti aukštesniame lygyje nei vandenynas, ir jos vandens lygis labiau priklauso nuo upių vandenu prietakos nei Šiaurès jūros patvankos. Ivairių šalių mokslininkai konstatuoja spartejjanti vandens lygio kilimą [5, 11, 13, 14]. 1988 m. Pasaulinè meteorologiné organizacija (WMO) ikūrè tarpvyriausybinę klimato kaitos tyrimo grupę (IPCC), kurioje ivvairių šalių mokslininkai daug demesio skiria vandens lygio kaitos kaip vieno iš svarbiausių klimato kaitos indikatorių analizei. Pagal ivvairius prognozinius skaičiavimus sudaryti scenarijai [10, 15]. Teigiama, kad šiltejant klimatui ir vandens temperatūrai, tirpstant ledynams, iki $2025 \mathrm{~m}$. pasaulio vandens lygis pakils nuo $8 \mathrm{iki} 25 \mathrm{~cm}$, o iki $2100 \mathrm{~m}$. - nuo 31 iki $110 \mathrm{~cm}$, priklausomai nuo regioninių variacijų.

Ne mažiau svarbus veiksnys, lemiantis daugiameti vandens lygio kitimą Baltijos jūroje, yra Žemès plutos judejjimas, kuris skirtingose jūros dalyse skiriasi ne tik dydžiu, bet ir kryptimi. 20 a. viduryje buvo taikomos Žemès plutos judesių ivvertinimo metodikos, pagristos daugiamečių vandens lygio duomenu sekų analizavimu $[4,16]$. Izoastiniai procesai nevienodai pasireiškia visame Baltijos jūros regione. Baltijos jūrą sąlygiškai padalijus skerspjūviu nuo Danijos sąsiaurių iki Suomijos įlankos, šiaurinèje dalyje dominuoja teigiamo ženklo žemès judesiai, o pietinèje dalyje - neigiamo. Izoastinių procesu intensyvumą iš dalies rodo daugiametè vandens lygio kaita įvairiuose Baltijos jūros regionuose (1 pav.).

Skandinavijos šalių teritorijoje Žemès pluta kyla, nes istorijos požiūriu ji visai neseniai yra išsivadavusi nuo ledynų masès spaudimo. Pietrytinè Baltijos jūros dalis, priklausanti senajai Rusijos platformai, atvirkščiai, iš lèto grimzta. Vandens lygio kitimui įvertinti tiksliau būtini Žemès plutos judesių tyrimai.

Ivairiuose literatūriniuose šaltiniuose aptinkamos skirtingos Žemès plutos grimzdimo mūsų regione reikšmès. Jos varijuoja nuo 0 iki $-2 \mathrm{~mm}$ per metus $[1,5$, 17, 18].

Šio darbo tikslas - remiantis surinktos medžiagos bei literatūros duomenimis, pateikti Kuršių marių bei Baltijos jūros vandens lygio daugiamečiu svyravimų Lietuvos regione metodologinius ypatumus.

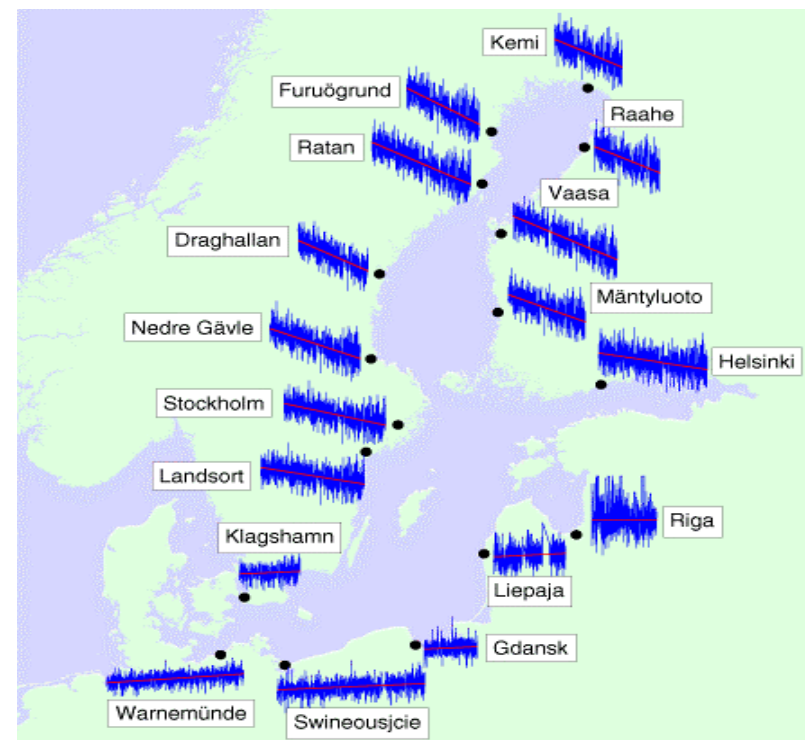

1 pav. Daugiametė vandens lygio kaita ịvairiuose Baltijos jūros regionuose

Fig 1. Changes of water level in Baltic sea regions

\section{Tyrimų objektas ir metodai}

Siekiant, kad vandens lygio duomenys būtų reprezentatyvesni, darbe remtasi kuo ivairiausiais duomenų šaltiniais. Straipsnyje, lyginant įvairių stočių duomenų absoliučiąsias reikšmes, santykinius svyravimo dydžius bei bendrą daugiametę vandens lygio kaitos tendenciją, detaliau analizuojamas laikotarpis nuo 1961 metų, kadangi iki šių metų vandens lygis buvo matuojamas pagal skirtingus atskaitos taškus, taikant skirtingas aukščiu sistemas. Darbe, remiantis 7 vandens lygio stočiu - Klaipèdos sąsiaurio, Šventosios, Palangos, Juodkrantès, Nidos, Ventès, Uostadvario duomenimis, analizuojami daugelio metu vandens lygio kaitos ypatumai Lietuvai priklausančioje pietrytineje Baltijos jūros dalyje ir Kuršių mariose. Stočių išsidèstymas pavaizduotas 2 paveiksle.

Darbe duomenys analizuojami aprašomaisiais statistiniais metodais. Apskaičiuoti tiesiniai trendai pagal vidutinių mėnesinių ir vidutinių metinių vandens lygių duomenu sekas. Ivertinta vandens lygio kitimo sparta. Siekiant objektyviau nustatyti daugiametes tendencijas, ne tik atlikta santykiniu vandens lygio svyravimą nusakančių dydžių lyginamoji analizè, bet ir slankiujų 10mečiu metodu eliminuota trumpalaikiu bei atsitiktinių svyravimų reikšmès. Apskaičiuoti pavienių stočių vidutiniai ménesiniai, daugiamečiai vandens lygiai. Vidutinis vandens lygis skaičiuotas nustatant vandens lygio reikšmių aritmetini vidurkị iš viso matavimų periodo duomenu sekos. Priklausomai nuo duomenu rinkimo trukmès periodo gautos daugiametès vidutinès paros, mènesio, sezono vandens lygio reikšmès. Vidutiniai paros vandens lygiai skaičiuoti pagal pirminius kasvalandinius ar valandinius (2-4 kartai per para) vandens lygio matavimo duomenis, saugomus chronologinių lentelių pavidalu Jūrinių tyrimų centro fonduose. 


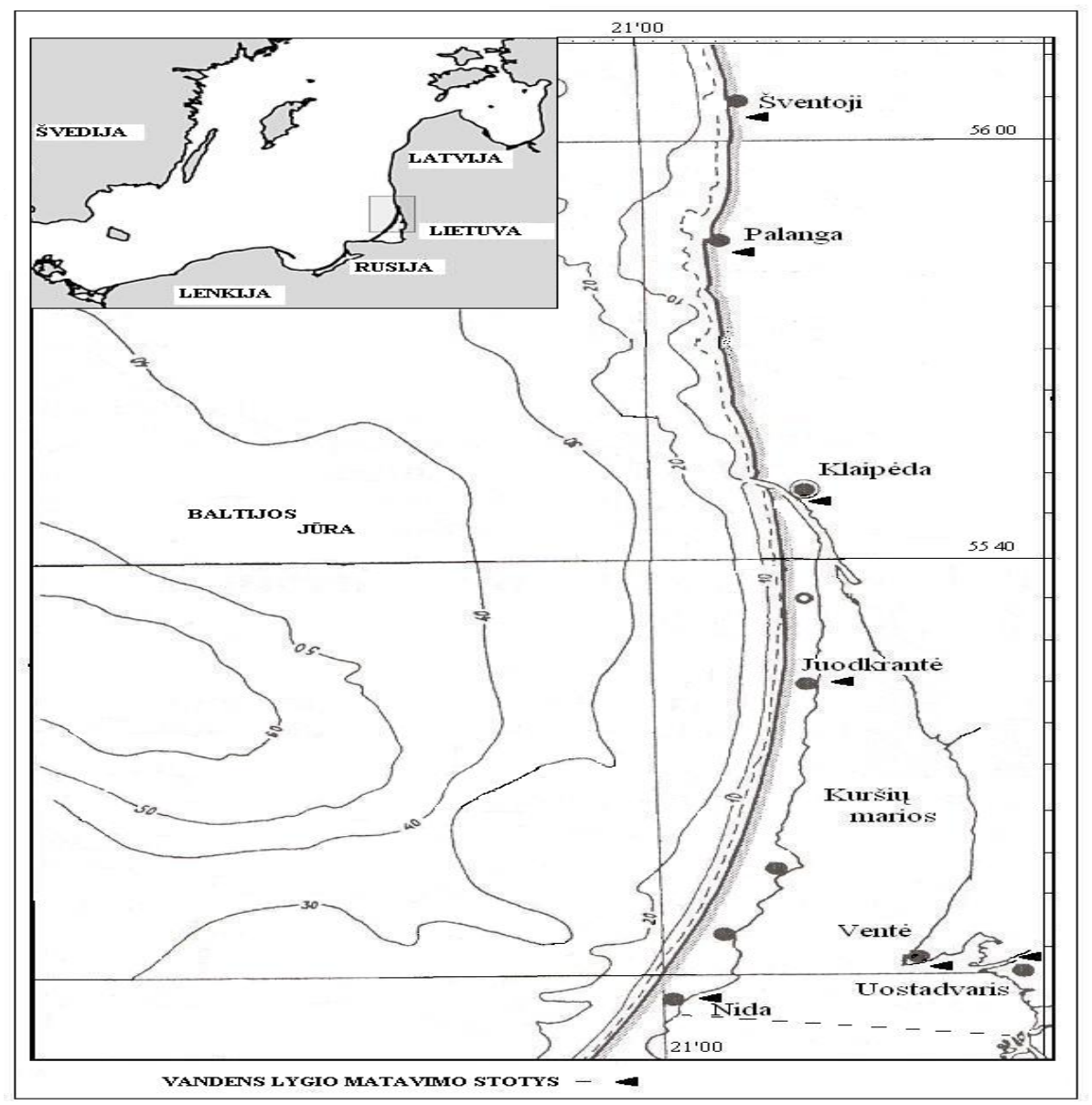

2 pav. Vandens lygio stočiu išsidèstymo schema

Fig 2. Scheme of water level observing stations

Vidutiniai mėnesiniai vandens lygiai skaičiuoti remiantis vidutinėmis paros vendens lygių reikšmėmis, vidutiniai metiniai - pagal vidutinius mėnesinius. Vidutinès daugiametès reikšmès apskaičiuotos pagal vidutines metines vandens lygio reikšmes.

Vandens lygio kaitos sparta analizuojama remiantis Klaipedos, Ventès, Nidos ir Juodkrantès hidrometriniu stočių ilgalaikių vidutinių metinių $(\mathrm{Hi})$ vandens lygių duomenimis. Skaičiuota taikant tiesinę regresijos lygti, išreiškiančią vienakryptę vandens lygio kitimo tendenciją laiko atžvilgiu. Vandens lygio kaitos sparta (v) išreiškiama mm per metus:

$$
v=\frac{\sum_{i=1}^{n}(H i-(-20)) T i}{\sum_{i=1}^{n} T i^{2}} .
$$

Išraiška (-20) yra sąlygiškai priimta nulinė reikšmė, t. y. pasirinktine mažiausioji vandens lygio duomenų eilès reikšmè, ją taikydami $(H i-(-20))$ gauname teigiamą duomenų eilę. Ši reikšmé kiekvienai pavienių stočių duomenu sekai skirtinga. (Ti) - laiko kintamoji, čia $(i)-$ duomenų eilès numeris. Regresijos lygtis igyja tokią formą:

$$
H i-(-20)=v T i+B,
$$

čia $B$ - laisvasis narys, gaunamas:

$$
B=\sum_{i=1}^{n} \frac{(H i-(-20))}{n} .
$$

Ivertinamas vandens lygio kaitos spartos skaičiavimų tikslumas::

$$
\sigma v= \pm \frac{M h}{\sqrt{\sum_{i=1}^{n} T i^{2}}}
$$

čia

$M h= \pm \sqrt{\frac{\sum_{i-1}^{n}(H i-(-20))^{2}-v \sum_{i-1}^{n}(H i-(-20)) T i-B \sum_{i-1}^{n}(H i-(-20))}{n-1}}$

Ši metodika buvo taikoma îvertinant Žemès plutos judejjimo greiti ir kryptị, priimant hipotezę, kad nèra jokio kito poveikio [16]. Nes tuo metu buvo teigiama, kad Baltijos jūroje eustatinis vandens lygio kilimas yra nereikšmingai mažas, todèl turint ilgalaikes vandens lygio duomenu eiles galima îvertinti Žemès plutos judesių spartą ir kryptị. Šiame darbe šis metodas taikomas siekiant ivertinti tik vandens lygio kitimo sparta ivairiais laikotarpiais bei skirtinguose vandens lygio matavimo taškuose. Būtina pažymèti, kad šiuo atveju neatsižvelgiama i kitus veiksnius, lemiančius vandens lygio kaita, bei nèra eliminuojami galimi Žemès plutos pokyčiai. 
1 lentelè. Vandens lygio matavimo stotys, jų veikimo laikotarpiai ir vidutiniai daugiamečiai vandens lygiai

Table 1. Water level observing stations, their functioning periods and mean secular water levels

\begin{tabular}{|c|c|c|c|c|}
\hline $\begin{array}{l}\text { Vandens lygio } \\
\text { matavimo stotis }\end{array}$ & $\begin{array}{l}\text { Stebèjimų } \\
\text { laikotarpis }\end{array}$ & Koordinatès & $\begin{array}{l}\begin{array}{l}\text { Vidutinis daugiametis vandens lygis, } \\
\mathrm{cm}\end{array}\end{array}$ & Paklaida $\sigma, \mathrm{cm}$ \\
\hline Šventoji & $\begin{array}{l}1926-1931 \\
1945-1958\end{array}$ & (nežinomos) & 0,8 & 6,2 \\
\hline Palanga & 1923-1925 & $55^{\circ} 55$ š. pl. $/ 21^{\circ} 03$ r. ilg. & $-1,7$ & 6,4 \\
\hline Klaipèda & $\begin{array}{l}1898-1940, \\
1949-2002 \\
\end{array}$ & $55^{\circ} 42,5$ š. pl. $/ 21^{\circ} 07,2$ r. ilg. & $-1,2$ & 7,9 \\
\hline Juodkrantè & $\begin{array}{l}\text { 1901-1915, } \\
1925-1938, \\
1955-2002 \\
\end{array}$ & $55^{\circ} 31,9$ š. pl. $/ 21^{\circ} 07,6$ r. ilg. & 5,8 & 7,4 \\
\hline Nida & $\begin{array}{l}1925-1938 \\
1948-2002\end{array}$ & $55^{\circ} 17,9$ š.pl. $/ 21^{\circ} 00,8$ r. ilg. & 8,2 & 7,7 \\
\hline Ventè & $\begin{array}{l}1925-1942 \\
1955-2002\end{array}$ & $55^{\circ} 20,0$ š. pl. $/ 21^{\circ} 10.2$ r. ilg. & 4,8 & 8,1 \\
\hline Uostadvaris & $\begin{array}{l}1901-1915, \\
1925-1932, \\
1961-1965, \\
1973-1985, \\
1997-2002\end{array}$ & $55^{\circ} 20,7$ š. pl. $/ 21^{\circ} 17,4$ r. ilg. & 21,3 & 8,3 \\
\hline
\end{tabular}

\section{Tyrimų rezultatai}

Vidutinè per visą stebejjimų laikotarpi apskaičiuota vandens lygiu reikšmė atspindi vidutinị daugiametị lygị. Tačiau apskaičiavus Kuršių marių vandens lygių matavimo postų - Klaipèdos, Ventès, Nidos, Juodkrantès, Uostadvario - vidutinius daugiamečius vandens lygius, paaiškejjo, kad Ventès daugiametis vandens lygis abejotinas (1 lentelè). Jis net $4 \mathrm{~cm}$ žemesnis už Nidos vidutini daugiameti vandens lygi. Susidaro lyg įdubimas tarp Uostadvario ir Nidos, prieštaraujantis visiems gamtos dèsniams. 1 lentelèje pateiktos stočių koordinatès bei veikimo periodai, matavimų dažnumas bei vandens lygiu aritmetiniai vidurkiai.

Vandens lygio matavimų tikslumas labai priklauso nuo sąsajos su valstybine aukščiu sistema tikslumo. Bendra aukščiu sistema suteikia galimybę lyginti skirtingu postų vandens lygius, skaičiuoti vandens lygių paaukštejjimus, o kartu ir vandens nuotèki, debitus. Tačiau patikrinus įvairių epochų, t. y. 1951 m., 1977 m., $1986 \mathrm{~m}$. ir $1993 \mathrm{~m}$. atliktų valstybinių niveliacijų duomenis, kontroliniu, darbiniu reperiu altitudes ir sulyginus su priekrantinių postų techninių bylų, niveliacijų žurnalų duomenimis paaiškejjo, kad ligi šiol vandens lygis skaičiuojamas pagal $1951 \mathrm{~m}$. niveliacijos apibrèžtą Baltijos aukščiu sistemą, išskyrus Klaipėdos sąsiauri, kuriame vandens lygis nuo 1996 m. matuojamas remiantis $1993 \mathrm{~m}$. niveliacija, atlikta pagal tarptautini „Baltijos jūros lygio“ projektą [19].

Palyginus 1951 m., 1977 m., 1986 m. ir 1993 m. niveliacijų reperių altitudes [20, 21], apskaičiavus paaukštejjimu skirtumus ir ivedus daugiamečiu vandens lygiu pataisą, gaunamas geresnis rezultatas. Vidutinis daugiametis vandens lygis ties Vente pagal $1977 \mathrm{~m}$. Baltijos aukščiu sistemą $5,5 \mathrm{~cm}$ aukštesnis, o kartu aukštesnis už Nidos daugiameti vandens lygi (2 lentelè). Matyt, visų 1977 m. niveliacijos rezultatų bei tų metu reperių aukščiu sistemos buvo atsisakyta dèl klaidų, padarytų atliekant niveliaciją Klaipėdoje (kaip matome 2 lentelèje). Iš esmès 1986 m. ir 1993 m. niveliacijos buvo tikslesnès.

Atlikę ilgiausios turimos duomenų sekos filtraciją pagal slenkančiuosius dešimtmečius gauname, kad vandens lygis 20 a. pradžioje pažemejo beveik $5 \mathrm{~cm}$ (3 pav.). Antraji dešimtmeti jis išlieka stabilus. Nedidelis vandens lygio pakilimas nustatytas trečiajame dešimtmetyje. Vèliau, maždaug iki 1940 m., jis sumažèjo $2-5 \mathrm{~cm}$. Po II pasaulinio karo vandens lygis pakito nuo 2 iki $5 \mathrm{~cm}$. Ryškesnè teigiamo trendo tendencija pasireiškia tik 20 a. pabaigoje, nuo 8 dešimtmečio.

2 lentelè. Reperių aukštis (m), apskaičiuotas atliekant niveliacijas skirtingais laikotarpiais (*papildomas reperis)

Table 2. Heights of benchmarks (m) calculated from levellings in different epochs (*additional benchmark)

\begin{tabular}{|l|c|c|c|c|l|c|c|c|c|}
\hline $\begin{array}{l}\text { Vandens lygio } \\
\text { matavimo stotys }\end{array}$ & $1951 \mathrm{~m}$. & $1977 \mathrm{~m}$. & $\begin{array}{l}\text { pataisa } \\
(\mathrm{cm})\end{array}$ & $1986 \mathrm{~m}$. & $\begin{array}{l}\text { pataisa } \\
(\mathrm{cm})\end{array}$ & $1993 \mathrm{~m}$. & $\begin{array}{l}\text { pataisa } \\
(\mathrm{cm})\end{array}$ & $\begin{array}{l}\text { vid. vand. } \\
\text { lygis }\end{array}$ & $\begin{array}{l}\text { Ivedus } \\
\text { pataisą }\end{array}$ \\
\hline Klaipéda & 3,529 & 3,543 & $-1,4$ & & & 3,536 & $+0,7$ & $-1,22$ & $\mathbf{- 0 , 5 2}$ \\
\hline Nida & 2,002 & 1,993 & $-0,9$ & & & & $-0,9$ & 8,33 & $\mathbf{7 , 4 3}$ \\
\hline Juodkranteं* & $* 1,566$ & & & $1,588^{*}$ & $+2,0$ & & $+2,0$ & 5,83 & $\mathbf{7 , 8 3}$ \\
\hline Juodkrante் & 2,889 & 2,921 & $+3,2$ & 2,914 & $+2,5$ & & $+2,5$ & 5,83 & $\mathbf{8 , 3 3}$ \\
\hline Vente் & 3,812 & 3,867 & $+5,5$ & 3,867 & $+5,5$ & & $+5,5$ & $\mathbf{4 , 7 6}$ & $\mathbf{1 0 , 2 6}$ \\
\hline Uostadvaris & 0,442 & & & 0,412 & $-3,0$ & & $-3,0$ & 21,30 & $\mathbf{1 8 , 3}$ \\
\hline
\end{tabular}




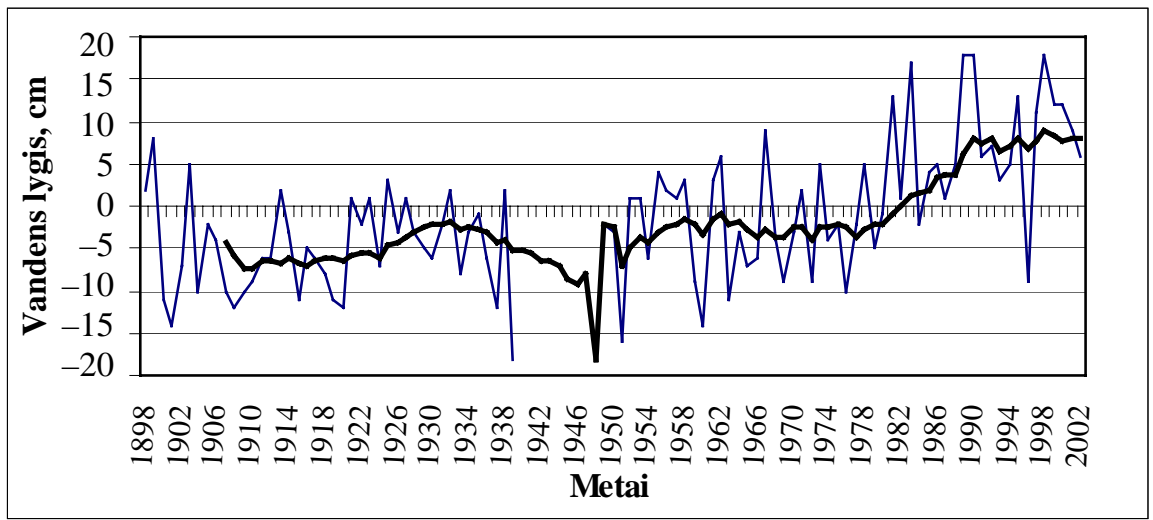

3 pav. Vidutinių metinių vandens lygių kaita Klaipėdos sąsiauryje ir slenkančiujjų dešimtmečiu kreivė, 1898-2002 m.

Fig 3. Change of water level at Klaipeda strait and curve of moving decades, 1898-2002

Vandens lygio kaitos režimas ir sąiauryje, ir centrinèje marių dalyje ties Nida maždaug iki 20 a. aštuntojo dešimtmečio turèjo tendenciją kisti nežymiai (4 pav.). Tačiau 8-9 dešimtmečiais fiksuojamas staigesnis kilimo šuolis. Panaši vandens lygio kaitos tendencija pasireiškia visų nagrinėjamu vandens lygio matavimo stočiu duomenų sekose (3-5 pav.). Daugiametèje vandens lygio kaitos dinamikoje ivairiais laikotarpiais nustatyta ¿̇vairūs tiek teigiami, tiek neigiami kitimo laikotarpiai. Tačiau teigiamo ženklo trendas labiau pasireiškè tik nuo 8 dešimtmečio. Labiausiai vandens lygio kaitai, kaip ir visiems hidrodinaminiams procesams, itakos turejjo atmosferiniu procesų kaita. Vandens lygių svyravimai labai susiję su atmosferinių procesų kaita šiaurès Atlante bei Baltijos jūros regione [13]. Susidarius jūrinio vandens patvankai vandens lygio trendų kilimas mažèja nuo Klaipèdos sąsiaurio Kuršių marių centrinès dalies link (5 pav.).

Vandens lygio kitimo ivairiais laikotarpiais sparta, remiantis Klaipédos, Ventès, Nidos ir Juodkrantès hidrometrinių stočiu vidutinių metinių vandens lygių duomenimis, yra nevienoda. Iki Antrojo pasaulinio karo buvo nustatyta nežymi kilimo tendencija. Nuo $1960 \mathrm{~m}$. vidutinis vandens lygis kyla maždaug $3,0 \mathrm{~mm}$ per metus greičiu: Klaipèdos sąsiauryje $-3,48 \mathrm{~mm} /$ metus, Kuršiu mariose ties Nida - 3,20 $\mathrm{mm} / \mathrm{metus}$, ties Vente $3,30 \mathrm{~mm} /$ metus, ties Juodkrante $-2,67 \mathrm{~mm} / \mathrm{metus}$. Nuo 20 a. vidurio vandens lygis kyla vis sparčiau. 2 lentelejje pateikti duomenys [16], gauti taikant Žemès plutos judejjimo spartą ivertinančią metodiką [16]. Juos i̇domu palyginti su šiame darbe gautais skaičiavimų rezultatais (3 lentelè). Kaip matome, Lietuvos regione visais laikotarpiais dominuoja vandens lygio kilimo tendencija. Klaipèdos sąsiauryje ir Kuršiu mariose vandens lygio kilimo reikšmès skirtingose stotyse tais pačiais laikotarpiais skiriasi labai nežymiai (3-5 lentelès).

Remdamiesi ilgiausia Klaipèdos sąsiaurio vandens lygio duomenu seka galime teigti, kad šiame regione vandens lygis maždaug per 100 metų (1898-2001) pakilo apie 13,5 centimetro. Šis skaičius neblogai atitinka vokiečiu mokslininko H. J. Stigge teigimą [22], kad pietrytinèje centrinès Baltijos jüros dalyje vandens lygis per šimtmetị vidutiniškai pakilo $15 \mathrm{~cm}$. Vandens lygis pietrytinėje Baltijos jūros dalyje ir Kuršiu mariose tendencingai kyla. Nuo 20 a. aštuntojo dešimtmečio pasireiškusią staigią vandens lygio kilimo tendenciją sudètinga būtų paaiškinti vien eustatiniais ar geotektoniniais procesais.

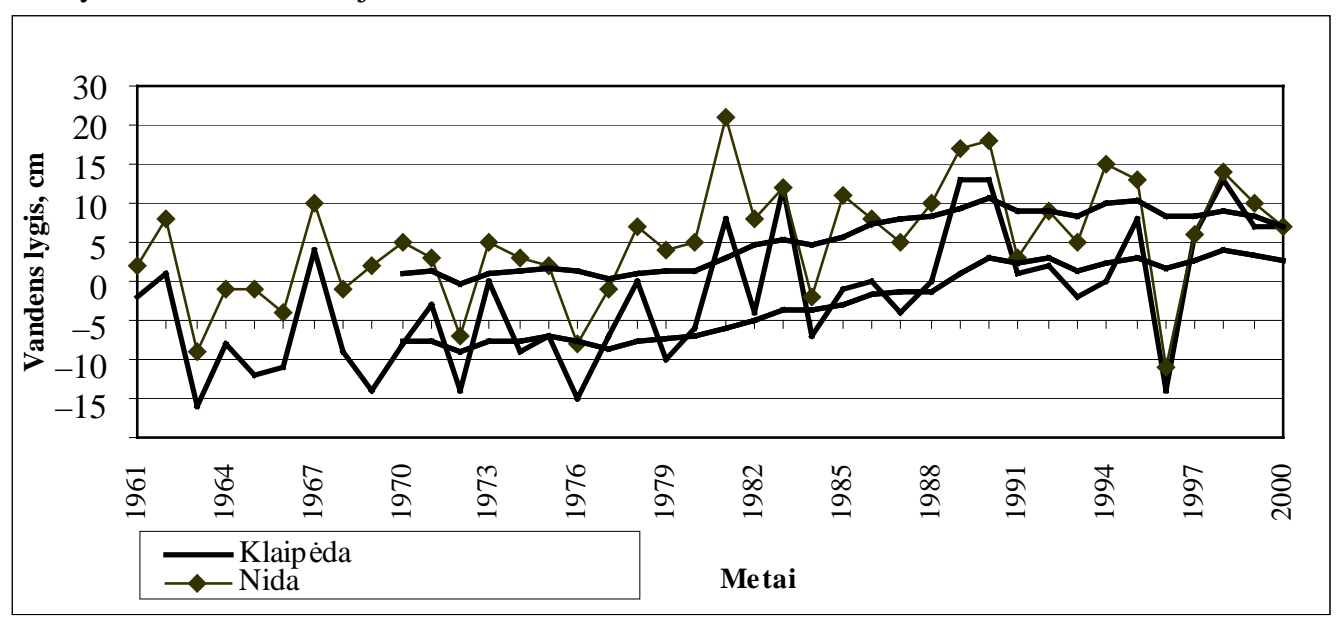

4 pav. Vidutinių metinių vandens lygių kaita Klaipėdos sąsiauryje, Kuršiu mariose ties Nida ir slenkančiujų dešimtmečiu kreivės, 1961-2000 m.

Fig 4. Change of water level at Klaipeda strait, in Curonian lagoon at Nida, and curve of moving decades, 1961-2000 


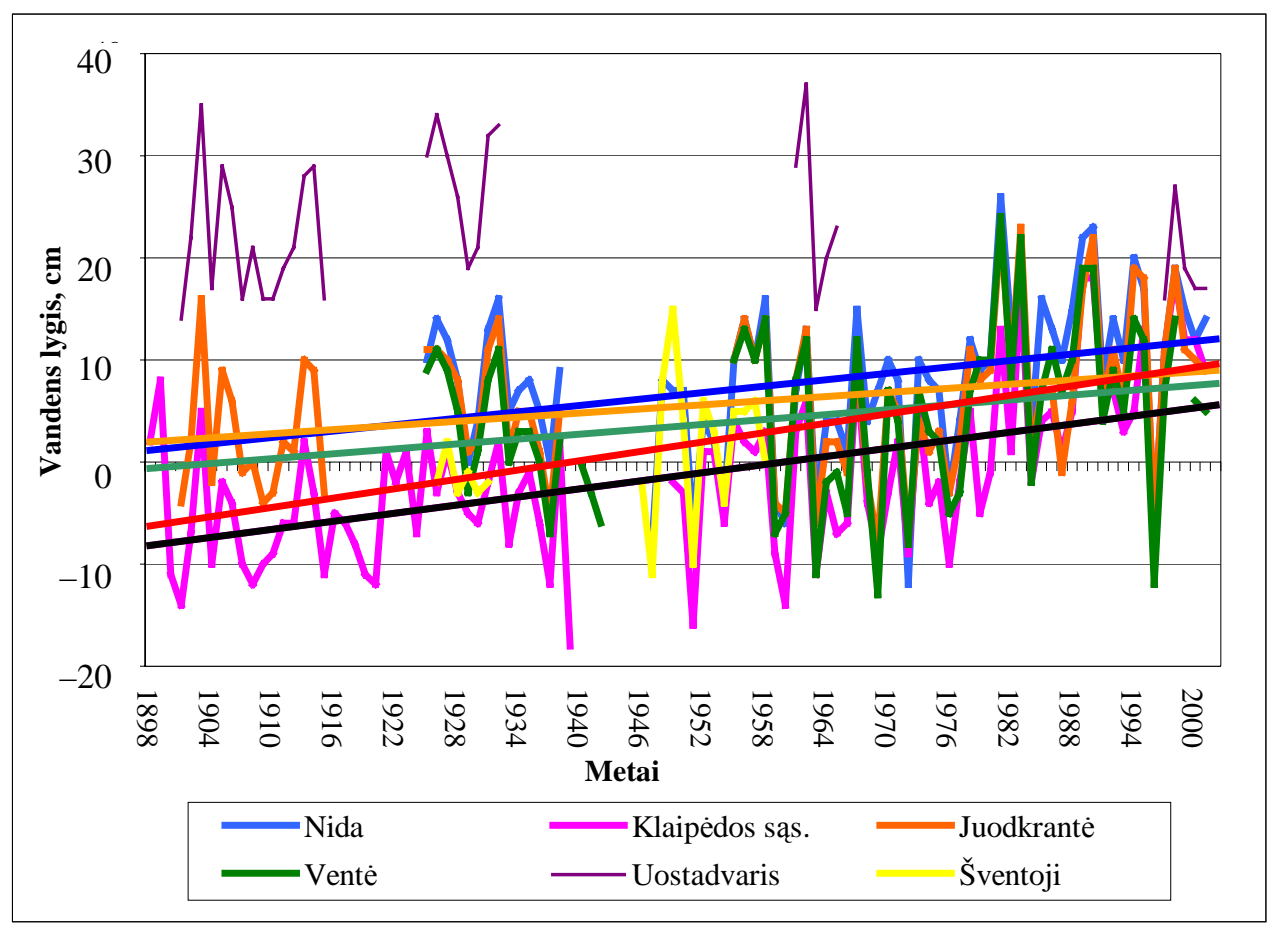

5 pav. Vidutinių metiniu vandens lygių kaita Kuršiu mariose ir pietrytinėje Baltijos jūros priekrantejje bei vandens lygio kitimo trendai, 1989-2002 m.

Fig 5. Change of water level at Klaipeda strait, at south-east of Baltic sea and trends of water level changes, 1989-2002

3 lentelè. Vandens lygio kitimo greitis $\mathrm{mm} /$ per metus [16]

Table 3. Speed of water level changes mm/year [16]

\begin{tabular}{|l|l|l|l|}
\hline Vandens lygio matavimo stotis & Periodas & Greitis, $\mathrm{mm} / \mathrm{metus}$ & Tikslumas $\sigma \mathrm{v}, \mathrm{mm} / \mathrm{metus}$ \\
\hline Šventoji & $1926-1958$ & $+1,10$ & $\pm 0,34$ \\
\hline Ventė & $1925-1968$ & $+1,10$ & $\pm 0,30$ \\
\hline Uostadvaris & $1902-1932$ & $+1,10$ & $\pm 0,30$ \\
\hline Nida & $1948-1968$ & $+3,20$ & $\pm 0,30$ \\
\hline Juodkrante் & $1902-1968$ & $+1,40$ & $\pm 0,20$ \\
\hline
\end{tabular}

4 lentelè. Vandens lygio kitimo greitis $\mathrm{mm} / \mathrm{per}$ metus

Table 4. Speed of water level changes $\mathrm{mm} / \mathrm{year}$

\begin{tabular}{|l|l|l|l|}
\hline Vandens lygio matavimo stotis & Periodas & Greitis, mm/metus & Tikslumas $\sigma v, \mathrm{~mm} / \mathrm{metus}$ \\
\hline Klaipéda & $1960-2001$ & $+3,48$ & $\pm 0,87$ \\
\hline Nida & $1960-2001$ & $+3,20$ & $\pm 0,77$ \\
\hline Vente & $1960-2001$ & $+3,30$ & $\pm 0,98$ \\
\hline Juodkrante & $1960-2001$ & $+2,67$ & $\pm 0,88$ \\
\hline
\end{tabular}

5 lentelè. Vandens lygio kitimo greitis mm per metus Klaipèdos vandens lygio matavimo stotyje skirtingais laikotarpiais Table 5. Speed of water level changes $\mathrm{mm} /$ year at Klaipeda water level observing station in different epochs

\begin{tabular}{|c|c|c|}
\hline Periodas & Greitis, $\mathrm{mm} / \mathrm{metus}$ & Tikslumas $\sigma v, \mathrm{~mm} / \mathrm{metus}$ \\
\hline $1898-2001$ & $+1,36$ & $\pm 0,20$ \\
\hline $1949-2001$ & $+3,03$ & $\pm 0,55$ \\
\hline $1970-2001$ & $+4,58$ & $\pm 1,24$ \\
\hline
\end{tabular}

Matyt, vandens lygio kilimą pastaraisiais dešimtmečiais reikètų sieti su dažnèjančia šiltų ir drègnų oro masių advekcija šaltuoju periodu, su globaliaisiais atmosferos cirkuliacijos pokyčiais, stiprejjančia pernaša vakarų kryptimi, kylančia oro temperatūra, šiltomis žiemomis, kai iškrinta žymiai daugiau kritulių, mažèja dienų, kai yra sniego danga, su stiprejjančiu makrocirkuliacinių procesų ne tik Lietuvos teritorijoje, poveikiu [11, 14, 23-26].

\section{Išvados}

1. Remiantis daugiamečiais Klaipèdos sąsiaurio (1898-2001 m.) vandens lygio duomenimis, vandens lygis per šimtmetị ties Lietuvos krantais pakilo $13,5 \mathrm{~cm}$. Nuo 1960 metų vidutinis vandens lygis kyla maždaug 3,0 mm per metus greičiu.

2. Spartejanti vandens lygio kilimo tendencija labai nepalanki Lietuvai krantų irimo atžvilgiu, nes, kylant 
vandens lygiui, bangu ardomasis poveikis gali pasireikšti vis didesnejje kranto dalyje.

3. Vandens lygio kilimas Lietuvos regione sietinas su dažnėjančia šiltų ir drègnų oro masių advekcija šaltuoju periodu, su globaliaisiais atmosferos cirkuliacijos pokyčiais.

4. Analizuojant daugiamečio jūros vandens lygio svyravimo ypatumus Lietuvos regione, būtina įvertinti Žemès plutos judesių itaką.

\section{Literatūra}

1. Baerens, Ch.; et al. Die Küste. Die Wasserstände an der Ostseeküste. Entwicklung - Stumfluten - Klimawandel. Archive for researh and technology on the North sea and Baltic coast, 2003. 331 p.

2. Dubra, J. Peculiarities of the sea level changes (Vandens lygio svyravimų ypatybès). Kuršių marios. 1978, p. 7-16 (in Lithuanian).

3. Žaromskis, R. Oceans, seas, estuaries (Okeanai, jūros, estuarijos). Vilnius, 1996. 211 p. (in Lithuanian).

4. Lazarenko, N. N. Water level changes (Колебания уровня воды). Leningrad: Gidrometizdat, 1961. 108 p. (in Russian).

5. Jarmalavičius, D.; Žilinskas, G. Pecularities of the water level secular changes in the South and South-east Baltic sea (Pietinès ir Pietrytinès Baltijos jūros daugiamečiu vandens lygiu svyravimo ypatumai). Geography (Geografija), No 32. 1996, p. 28-32 (in Lithuanian).

6. Jarmalavičius, D.; Žilinskas, G. Secular changes of the Baltic sea level (Daugiamečiai Baltijos jūros lygio svyravimai). In: Lietuva - jūrų valstybè. Lietuvos okeanologų konferencijos medžiaga, 1996. p. 120-126 (in Lithuanian).

7. Lapinskaite, A.; Pustelnikovas, O.; Želvytè, D. Sustainable development of Klaipeda sea port (Subalansuota Klaipédos uosto plètra). 2002. 191 p. (in Lithuanian).

8. Reference book on hydrogeological regime of seas and estuaries of USSR. Baltic sea. (Справочник по гидрологическому режиму морей и устьев рек СССР. Балтийское море). Vol 1. Issue 4. 1973. 311 p. (in Russian).

9. Basalykas, A. Earth - humanity abode (Žemè - žmonijos buveinè). Vilnius, 1985. 256 p. (in Lithuanian).

10. IPCC climate change and sea level rise. Global climate change and the rising challenge of the sea. Intergovernmental panel on climate change response strategies working group coastal zone management subgroup May 1992, Netherlands, 1992, p. 5-10.

11. Kalas M.; Characteristic of sea level changes on the Polish coast of the Baltic Sea in the last forty five years. International Workshop, Sea Level Changes and Water Management, Session 1: Observed Sea Level Changes and Land Subsidence, 1993, I-51.

12. Raudsepp U.; Toompuu A.; Kouts T. A stochastic model for the sea level in the Estonian costal area. Journal of Marine Systems 22, 1999, 69-87.

13. Vorobjeb, B.H.; Kočanov, C.J.; Smirnov, H.P. Seasonal and secular changes of the seas of the North Arctic ocean (Сезонные и многолетние колебания морей Северного ледовитого океана). St. Peterburg, 2000. 113 p. (in Russian).

14. Fenger, J.; Buch, E.; Jacobsen, P.R. Monitoring and impacts of sea level rise at Danich coasts and near shore infrastructures. Climate change research, 2002, p. 237254.
15. Subrata P.; Zillur Rahman M.; Bhuiya A.H. Sea level rise and cyclonic disaster in the coastal belt of Bangladech: a perspective plan for disaster preparedness programme. International workshop. Sea level changes and water management. Session 6: Costal management and measures to sea level rise, 1993, VI - 25.

16. Calculation guide of the hydrological regime elements in the shelf and estuaries for the engineering investigations (Руководство по расчету элементов гидрологического режима в прибрежной зоне морей и в устьях рек при инженерных изысканиях). Moscow: Gidrometizdat, 1973. 535 p. (in Russian).

17. Makinen, J. Draft plan for absolute gravity campaigns in the Fennoscandian land uplift area. Nordiska Kommissionen for Geodesi. Nordic geodetic commission. Working Group for Geodynamics. 2003. $11 \mathrm{p}$.

18. Working group for height determination of the Nordic geodetic commission. Future height systems in the Nordic countries, their relation to the EVRS200 and to INSPIRE GIS standards. Position paper presented to the meeting of the TWG of the IAG Subcommission for the European Reference Frame (EUREF), Toledo, June 3, 2003.

19. Petroškevičius, P. Measurements in international project „Baltic sea level“ (Matavimai pagal tarptautini projektą „Baltijos jūros lygis“). Institute of Geodesy of Vilnius Technical University, 1993. 59 p. (in Lithuanian).

20. Technical project for connecting of tide gauges to the state first and second class levelling network by second order levelling (Технический проект на производство привязки уровенных постов нивелированием I и II классов. Объект Балтийск - Саласгрива. Шрифт объекта 05.03.1144). Главное управление геодезии и картографии при Совете Министров СССР. Предприятие № 5, 1986 (in Russian).

21. Technical report on connection the tide gauges of Baltic sea to state levelling network by second order levelling (Технический отчет о привязке нивелирной сети нивелированием II класса уровнемерных станций и водомерных постов, расположенных по побережью Балтийского моря. Объект Балтийск - Саласгрива. Шрифт объекта 05.03.1144). Главное управление геодезии и картографии при Совете Министров СССР. Предприятие № 5, 1986 (in Russian).

22. Stigge, H. J. Sea level changes and high-water probability on the German Baltic coast. Int. Workshop, Sea Level Changes and Water Management, Sesion 1: Observed Sea Level Changes and Land Subsedence. 1993. p. 1-19.

23. Bukantis, A.; at al. Climate changes influence to the physical geographical processes in Lithuania (Klimato svyravimu poveikis fiziniams geografiniams procesams Lietuvoje). Institute of Geography of Vilnius University, 2001. 280 p. (in Lithuanian).

24. Bukantis, A.; at al. Climate elements changes in the Lithuanian territory (Klimato elementu kintamumas Lietuvos teritorijoje). Vilnius, 1998. 171 p. (in Lithuanian).

25. Bukantis, A. Lithuanian climate (Lietuvos klimatas). Vilnius, 1994. 187 p. (in Lithuanian).

26. Tilickis. B.; Stankevičius, A. Hydrological regime at Baltic seashore ( Hidrologinis režimas Baltijos pajūryje). Sea and environment (Jüra ir aplinka), No 2. Klaipèda University, 1999, p. 27-36 (in Lithuanian). 